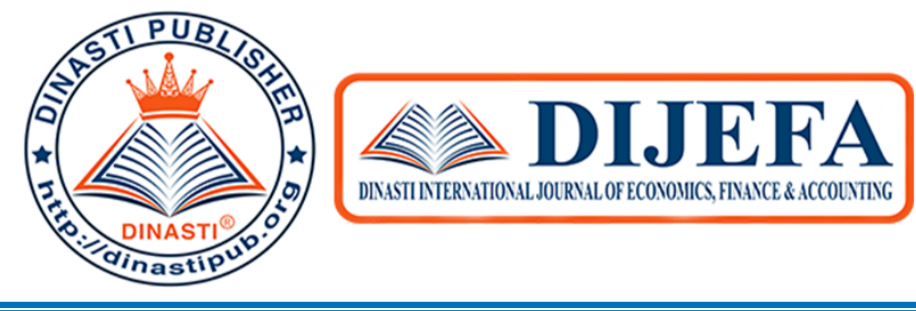

+6281387654578?

+6281387654578@

https://dinastipub.org/DIJEFA (-)

dinasti-info@gmail.com (G)

\title{
INFLUENCE OF CAREER DEVELOPMENT, WORK ENVIRONMENT, COMPENSATION AND IT'S IMPLICATION ON JOB SATISFACTION OF PERMANENT LECTURER AT MARITIME COLLEGES IN DKI JAKARTA
}

\section{Ali Muktar Sitompul ${ }^{1}$, Marhalinda ${ }^{2}$, Anoesyirwan Moeins ${ }^{3}$ \\ ${ }^{1)}$ Sekolah Tinggi Ilmu Pelayaran Jakarta, Indonesia \\ 2, 3) Universitas Persada Indonesia YAI}

ARTICLE INFORMATION

Received: $22^{\text {nd }}$ May 2020

Revised: $30^{\text {th }}$ June 2020

Issued: $7^{\text {th }}$ July 2020

Corresponding author: first author E-mail:

alimuktarsitompul@yahoo.com

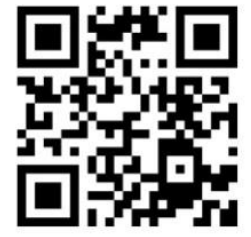

DOI:10.38035/DIJEFA
Abstract: This study aims to analyze and prove the Influence Career Development, Work Environment, Compensation and it's implication on job satisfaction of permanent lecturer of maritime colleges in DKI Jakarta both partially and simultaneously. The research method used is descriptive survey method and explanatory survey with 253 respondents. The analysis of the data used is Structural Equation Modeling (SEM), consisting of career development, work environment and compensation as exogenous variables, job satisfaction as an endogenous variable. Based on the partially and simultaneous research that Career development, work environment and compensation have a positive and significant effect on job satisfaction with a contribution $\left(\mathrm{R}^{2}\right)$ of $92 \%$. Work environment has the most dominantt effect on the job satisfaction of lecturers at maritime colleges in DKI Jakarta.

Keywords: Career development, work environment, Compensation, Job Satisfaction, SEM.

\section{INTRODUCTION}

The emerge of many maritime schools and institutions is one of the efforts by the government as a member of IMO (Intenational Maritime Organization). IMO is an international agency that specifically handles maritme issues in order to improve work and shipping safety, which in turn creates professional seafarers. Based on the IMO convention, it regulates a minimum standard of seafaring education and training which must be followed by every IMO member country. The job satisfaction is important for the institutions to achieve their goals. This can be seen based on data and job satisfaction, career development, work environment and compensation which are used as benchmarks 
for lecturers of maritime institutions. Slow career development can be seen from education, length of academic level, less conducive work environment, and inadequate compensation. The number of lecturers who gained promotion or rank as well as further education is still below the minimum standard.

This can be seen from the facts on the ground that can be presented in the following table:

Table 1. Distribution of Permanent Lecturers Based on Academic positions in 2016 and 2017

\begin{tabular}{|c|c|c|c|c|c|c|c|c|c|c|c|}
\hline \multirow{2}{*}{ No } & \multirow{2}{*}{ Academic Position } & \multicolumn{2}{|c|}{ STIP Jakarta } & \multicolumn{2}{|c|}{$\begin{array}{c}\text { STIMar - AMI } \\
\text { Jakarta }\end{array}$} & \multicolumn{2}{|c|}{$\begin{array}{l}\text { Aman Jaya } \\
\text { Jakarta }\end{array}$} & \multicolumn{2}{|c|}{$\begin{array}{l}\text { AMI Djadajat } \\
\text { Jakarta }\end{array}$} & \multicolumn{2}{|c|}{$\begin{array}{l}\text { AMP } \\
\text { Jakarta }\end{array}$} \\
\hline & & 2016 & 2017 & 2016 & 2017 & 2016 & 2017 & 2016 & 2017 & 2016 & 2017 \\
\hline 1 & Lecturer & 59 & 52 & 21 & 21 & 20 & 20 & 13 & 13 & 11 & 11 \\
\hline 2 & Assistant Professor & 56 & 63 & 12 & 12 & 11 & 11 & 10 & 10 & 8 & 8 \\
\hline 3 & Associate Professor & 21 & 21 & 4 & 4 & 4 & 4 & 2 & 2 & 1 & 1 \\
\hline 4 & Professor & - & - & - & - & - & - & - & - & - & - \\
\hline & Total & 136 & 136 & 37 & 37 & 35 & 35 & 25 & 25 & 20 & 20 \\
\hline
\end{tabular}

Source: Kopertis region III in 2017

The low job satisfaction of maritime institutions' lecturers in DKI Jakarta can be seen from the field observation result in which they are often late in giving instruction and only giving assignments to cadets, in fact many of them only give independent assignments then sign up for attendance and then leave class for purposes other than teaching. As seen in table 2 below:

Table 2. The level of lateness in teaching lecturer in maritime institutions in DKI Jakarta, academic year of 2016/2017 and 2017/2018

\begin{tabular}{|c|l|c|c|c|c|}
\hline \multirow{2}{*}{ No } & \multicolumn{2}{|c|}{ Department } & \multicolumn{2}{|c|}{$\begin{array}{c}\text { The level of lateness in teaching lecturer } \\
\text { academic year of 2016/2017 }\end{array}$} & \multicolumn{2}{c}{$\begin{array}{c}\text { The level of lateness in teaching } \\
\text { lecturer } \\
\text { academic year of } \\
2017 / 2018\end{array}$} \\
\cline { 2 - 6 } & & Odd Semester (\%) & $\begin{array}{c}\text { Even Semester } \\
(\%)\end{array}$ & Odd Semester (\%) & Even Semester (\%) \\
\hline 1 & Nautical & 42 & 44 & 44 & 46 \\
\hline 2 & Technical & 41 & 44 & 42 \\
\hline 3 & Port \& Shipping Management & 40 & 42 & 43 \\
\hline Averages & 41 & 43,33 & 43 \\
\hline
\end{tabular}

Source: Head of Department Monitoring

Based on table 2 above, it can be seen that the level of lecturers lateness in teaching is still quite high, namely academic year of $2016 / 2017$, by $41 \%$ in odd semester and $43.33 \%$ in even semester. And in the academic year of 2017/2018, 
increasing to $43 \%$ in the odd semester and $44.67 \%$ in the even semester. In addition, the amount of research and community service conducted by lecturers of maritime institutions in DKI Jakarta is still relatively low. As shown in table 3 below:

Table 3. The averages of research and community services by maritime college's lecturers in DKI Jakarta academic year of 2016/2017 and 2017/2018

\begin{tabular}{|c|c|c|c|c|c|}
\hline \multirow[t]{2}{*}{ No } & \multirow[t]{2}{*}{ Department } & \multicolumn{2}{|c|}{$\begin{array}{c}\text { The averages of research and community } \\
\text { services by maritime college's lecturers in } \\
\text { academic year of } 2016 / 2017\end{array}$} & \multicolumn{2}{|c|}{$\begin{array}{c}\text { The averages of research and community } \\
\text { services by maritime college's lecturers in } \\
\text { academic year of } 2017 / 2018\end{array}$} \\
\hline & & Research (\%) & $\begin{array}{c}\text { Community Services } \\
(\%)\end{array}$ & Research $(\%)$ & $\begin{array}{c}\text { Community Services } \\
(\%)\end{array}$ \\
\hline 1 & Nautical & 76 & 76 & 76 & 75 \\
\hline 2 & Technical & 76 & 77 & 75 & 76 \\
\hline 3 & $\begin{array}{l}\text { Port \& Shipping } \\
\text { Management }\end{array}$ & 78 & 76 & 77 & 75 \\
\hline & Averages & 76,67 & 76,33 & 76 & 75,33 \\
\hline
\end{tabular}

Source: KP3M Monitoring Results

Based on table 3 above, it can be seen that the average research and community service by the lecturers in DKI Jakarta is still quite low, namely in the 2016/2017 academic year, amounting to $76.67 \%$ and community service at $76.33 \%$. In the academic year of $2017 / 2018$ the number of studies was $76 \%$ and community service was $75.33 \%$.

\section{Problem Formulation :}

The low of job satisfaction, identified by the slow career development, the level of lateness in teaching in every class's meeting and the amount of research and community service by the lecturers. So the researcher try to formulate the problems as follows:

1. Is there any influence of career development on job satisfaction of maritime college's lecturers in DKI Jakarta?

2. Is there any influence of the work environment on job satisfaction of maritime college's lecturers in DKI Jakarta?

3. Is there any effect of compensation on job satisfaction of maritime college's lecturers in DKI Jakarta?

4. Is there any influence of career development, work environment and compensation together to the job satisfaction of maritime college's lecturers in DKI Jakarta?

\section{LITERATURE REVIEW}

\section{Job Satisfaction}

Each individual has different characteristics, so the level of job satisfaction also varies. According to Poltak L Sinambela (2016: 129) job satisfaction of lecturers is closely related to lecturer loyalty. Someone who feel satisfied in their work and will have high motivation and high participation, which in turn will increase their loyalty. Satisfaction is basically personal, just like a taste, but satisfaction here refers to the attitude of someone at work. According to Robbins (2013: 155) job satisfaction in general is a relationship between an individual and his work and the environment. Job satisfaction will arise if the individual likes the work, the compensation given and his environment and vice versa, there will be a sense of dissatisfaction if he does not like his work, the compensation provided is not appropriate, or even a bad working environment. 
To find out whether individuals feel satisfied or dissatisfied in certain situations, four theories are used; fulfillment theory, reward theory, discrepancy theory, and equity theory David J, Cherrington (2015; 306).

From the theoretical description above, it can be synthesized that job satisfaction is a general attitude towards work that reflects a pleasant experience at work and hopes for future experiences, which are manifested by emotional attitudes and work results that are efficient, effective, and productive.

\section{Career Development}

According to Mathis, Robert. L, Jackson and Jhon H (2011: 55), a career is a position that is related to the job that someone occupies throughout his/her life. According to Rivai, Ella Djauhari and Sagala (2013: 752) career development is the process of increasing individual work skills in order to achieve the desired career. Meanwhile Hadari, Nawawi (2012: 23) states that career basically means the order of work / position of a lecturer in his work history and curriculum vitae. The importance of career development is closely related to job satisfaction and lecturer loyalty. According to Yuniarsih (2013: 139), career development consists of:

a. Career Planning,

That is; how employees plan and achieve their own career goals,

b. Career Management.

This process shows how the organization designs and implements employee career development programs.

Handoko (2011: 121), defines a career as the sequence of a person's work related activities and behaviors and associated attitudes, values, and aspirations over the span of one's life. Andromike dalam Mangkunegara (2012:77), mengemukakan bahwa "career development, from the stand point of the organization, is the personal activity which helps individuals plan their future career within the enterprise, in order to help the enterprise achieve and the employee achieve maximum self-devlopment".

From the above theoretical description of career development, it can be synthesized that career development is the process of activities or actions taken by a lecturer to improve the ability and effectiveness of work in order to be able to spur him in making the best contribution to achieve and develop the desired career in the implementation of his/her duties.

\section{Work Environment}

The work environment can be interpreted as where someone works, as expressed by Jordan E. Ayan (2012: 98) that the environment includes "small universe": room, office, or home where we pass through the day and night and "big universe": city , countries and regions where we live. According to the view of Lawler and Ledford in Sonny (2014: 22) that, "the work environment is anything that exists around workers that can affect themselves in carrying out the tasks assigned, such as cleanliness, music, cool, peaceful and so on."

The work environment consists of: 
a. Physical work environment is all physical conditions that are around the workplace that can affect employees directly or indirectly. The physical work environment consists of:

1) Environment that is directly related to employees such as: work centers, work laboratories, simulator equipment, chairs, tables and so on.

2) Intermediary work environment or general environment which can also be called a work environment that affects the human condition, for example: temperature, air circulation, humidity, lighting, noise, mechanical vibrations, unpleasant odors, colors and others.

b. Non-Physical Work Environment that is all the circumstances that occur relating to work relationships, both relationships with superiors and fellow co-workers, or relationships with subordinates. As stated by Soelaiman Sukmalana (2010: 279) that, "both the good and the bad job satisfaction is influenced by one's abilities, attitudes and values embedded in a person, also influenced by the condition of the physical environment". Alex S Nitisemito (2011: 183) defines the work environment as, "Everything that exists around the workers that can influence themselves in carrying out the tasks being carried out." While the view of Bernardin and Russel (2012: 182) that the work environment must be arranged in order to create a healthy, safe, clean, comfortable and pleasant atmosphere that can reduce physical and mental stress and improve productivity and quality of work life. Sedarmayanti (2014: 1) states that, "The work environment is the overall tools and materials faced, the surrounding environment in which a person works, his work methods, and his work arrangements both as individuals and as groups".

From the theoretical description above, it can be synthesized that the work environment is a physical and non-physical work environment that provides cosiness for a person or group and facilitates doing the job well.

\section{Compensation}

According to Griffin \& Moorhead (2014), compensation is a reward given by an organization to someone in relation to work to provide job satisfaction for their loyalty.

Compensation consists of financial compensation and non-financial compensation as stated by Henry Simamora (2011: 442) that "the terminology or distribution of compensation is in the form of financial and non-financial compensation". Financial compensation consists of direct financial compensation consisting of payments obtained by employees in the form of salaries, wages, bonuses and commissions. Indirect financial compensation consists of advantages or benefits obtained by an employee from the work itself or from the psychological and or physical environment where the employee works.

Compensation given to employees must also be fair according to the level of workload, education and position. If not, there will be a conflict between employees, disappointment and work disatisfaction. As stated by Soelaiman Sukmalana (2010: 143) that: Work wages can be a source of dissatisfaction. A worker will compare his salary with other workers in the same organization, the difference between one another could cause dissatisfaction. If a wage is based on performance then high performers will be 
satisfied if they receive the same wage or may even be lower than low performance workers.

According to Malayu SP, Hasibuan (2013: 118) compensation is anything that is constituted or considered as an equivalent remuneration. According to Werther, William B and Keith Davis (2016: 52) compensation is what a worker receives in return for the work he/she provides. Both hourly wages and periodic salaries are designed and managed by human resource department.

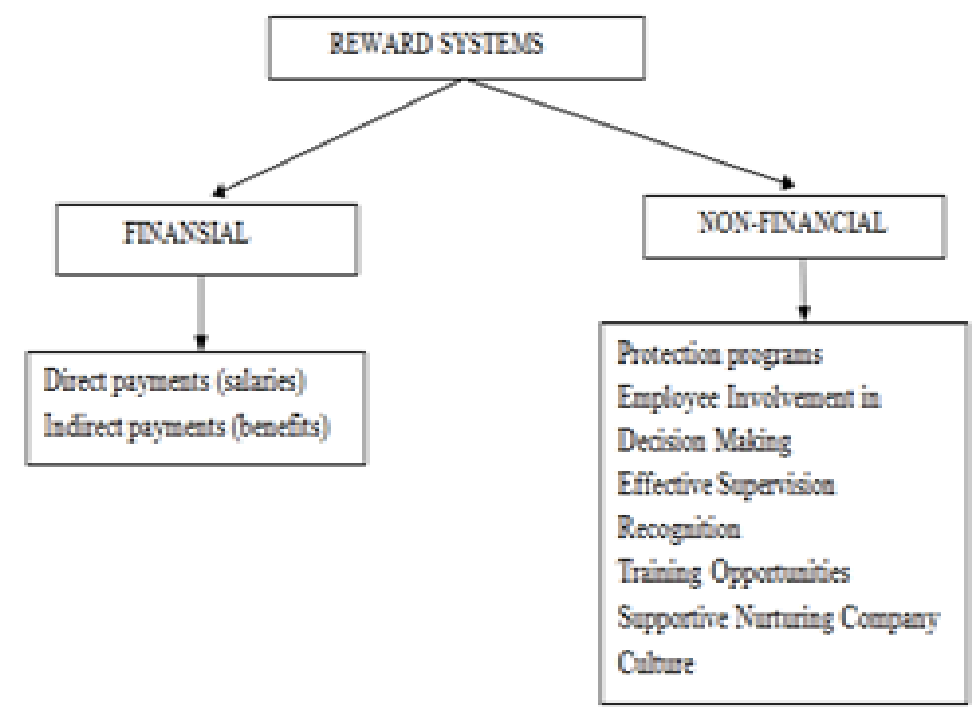

Figure 1. Reward System

Source: Cascio (2013 : 422)

Based on the figure above, financial reward in the form of direct reward can be in the form of salaries, transportation fees, holiday allowances, overtime payment, and other direct benefits. According to (Byars Lloyd L. and Rue W, Leslie, 2011: 241), organizational reward systems have a significant impact on employee job satisfaction. Furthermore, if the increase in rewards is associated with loyalty, employees who receive a healthy increase in rewards are usually more likely to experience feelings of achievement and satisfaction.

Table 8. Classification and Types Compensation

\begin{tabular}{|c|c|}
\hline \multicolumn{2}{|c|}{ Compensation } \\
\hline Direct & Indirect \\
\hline $\begin{array}{ll}\text { 1. } & \text { Wages } \\
\text { 2. Salary } \\
\text { 3. Bonus } \\
\text { 4. Incentives } \\
\text { 5. Shares }\end{array}$ & $\begin{array}{ll}\text { 1. } & \text { Allowance } \\
\text { 2. Health insurance } \\
\text { 3. Replacement holiday } \\
\text { 4. Pension fund } \\
\text { 5. Work compensation }\end{array}$ \\
\hline
\end{tabular}

Sources: Mathis and Jackson Management Human Resources, Book 3, 2011: 19.

From the theoretical description above, it can be synthesized that compensation is an award or reward contract performance for the use of energy, ability and skills for services and loyalty that have been given by individuals to the company or organization in the form of payment. 


\section{Theoretical Framework}

Based on the theoretical description above, the following framework is described:

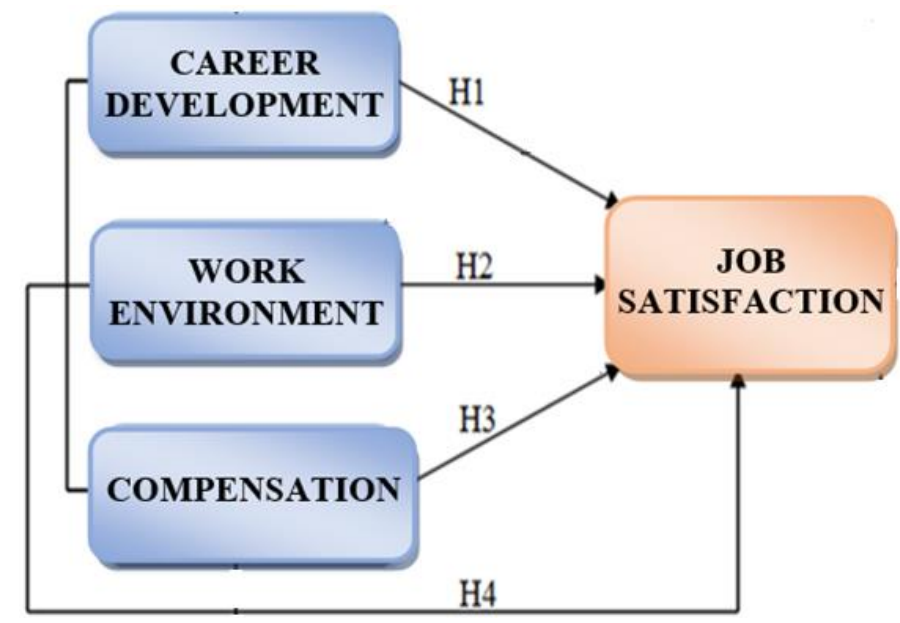

Figure 2. Theoretical Framework of The Research

\section{Research Hypothesis}

Based on the framework and research design models above, the following hypotheses can be formulated:

1. H1 $\rightarrow$ There is an influence of career development on job satisfaction of maritime of higher education institute in DKI Jakarta.

2. $\mathrm{H} 2 \rightarrow$ There is an influence of the work environment on job satisfaction of maritime of higher education institute in DKI Jakarta.

3. H3 $\rightarrow$ There is an effect of compensation on job satisfaction of maritime of higher education institute in DKI Jakarta.

4. $\mathrm{H} 4 \rightarrow$ There is an influence of career development, work environment and compensation together on job satisfaction of lecturers of maritime of higher education institute in DKI Jakarta.

\section{RESEARCH METHODS}

Referring to the problems and objectives of this study, the approach used is a survey with a descriptive and verification approach. Cause and effect analysis is needed to investigate the relationship and influence between the dependent variable (endogenous) and the independent variable (exogenous), so that it can be empirically examined and through accurate statistical analysis based on data in the field. So that, this study will examine whether or not career development, compensation, work environment affect job satisfaction.

The population in this study is a permanent lecturer in maritime colleges in DKI Jakarta. The sample size is determined by taking into account the analysis technique used in the hypothesis test which is the structural equation model (Structural Equation Model / SEM). Structural Equation Modeling (SEM), is a statistical modeling technique that is very cross-sectional, linear and general. In the SEM, factor analysis, path analysis and regression are involved. SEM is actually a hybrid technique that includes the 
confirmatory aspects of factor analysis, path analysis and regression that can be considered as special cases in SEM, Ali, H., \& Limakrisna, N. (2013).

\section{RESULTS AND DISCUSSION}

In this section, structural equation or the full Structural Equation Modeling model to answer hypotheses is applied. In Structural Equation Modeling there is no single statistical test tool to measure or test the model, generally there are various types of fit indexes used to measure the degree of conformity between the hypothesized model and the data presented. Therefore the model below used in data analysis is the Structural Equation Modeling method, so to be able to analyze the hypothesis of this study it is necessary to examine the suitability of the whole model (Goodness of Fit Structural Model). The complete model can be seen in the following image:

Figure 3. The Structural Model for Analysis of Standard Solution Measurement Model and Analysis of the Measurement Model t-values.

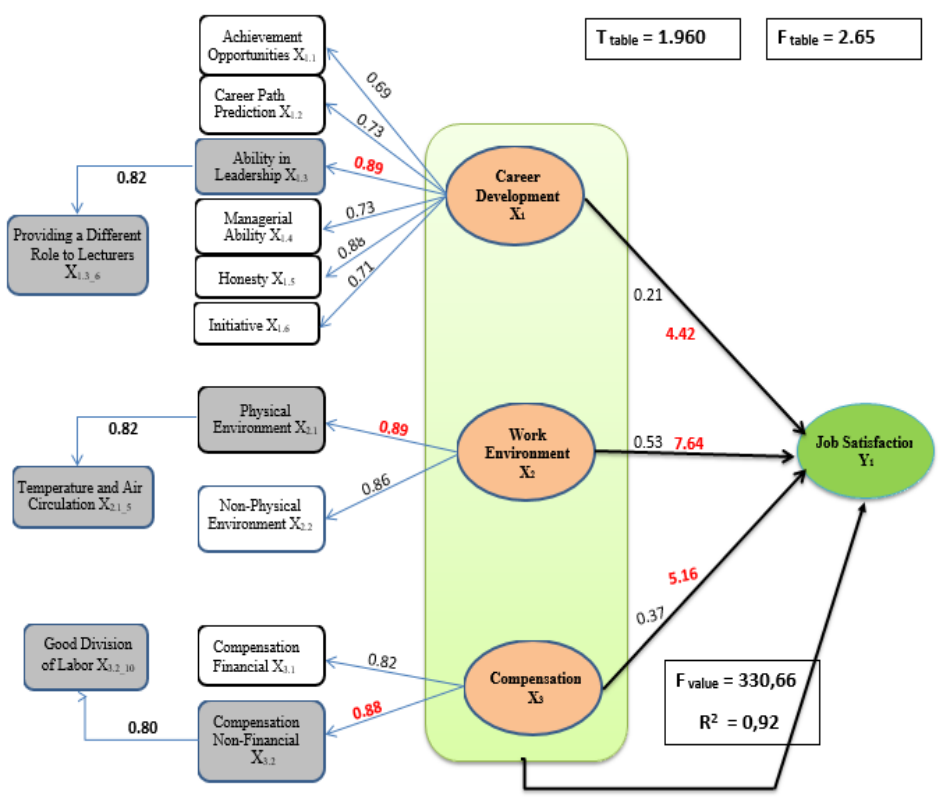

Structural equation

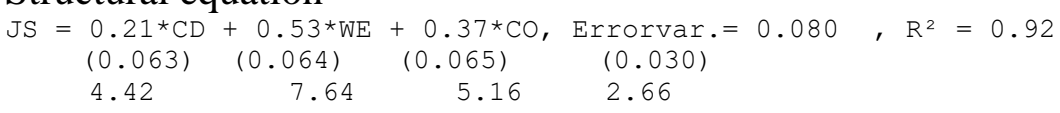

Source: Output Figure Appendix of Lisrel/SEM 
Table 9. Hypothesis test results

\begin{tabular}{|l|l|c|c|c|l|}
\hline \multicolumn{2}{|c|}{ Hypothesis } & $\begin{array}{c}\text { Path } \\
\text { Coefficient } \\
/ R^{2}\end{array}$ & $\begin{array}{l}\text { t-value/ } \\
\text { F value }\end{array}$ & $\begin{array}{l}\text { t table/ } \\
\text { F table }\end{array}$ & Statistical Conclusions \\
\hline $\mathrm{H}_{1}$ & $\begin{array}{l}\text { There is an influence of } \\
\text { career development on } \\
\text { job satisfaction of } \\
\text { maritime college } \\
\text { lecturers in DKI Jakarta. }\end{array}$ & 0,21 & 4,42 & 1.960 & $\begin{array}{l}\text { Career Development has a } \\
\text { positive and significant effect on } \\
\text { job satisfaction of maritime } \\
\text { college lecturers in DKI Jakarta }\end{array}$ \\
\hline $\mathrm{H}$ & $\begin{array}{l}\text { There is an influence of } \\
\text { the work environment } \\
\text { on job satisfaction of } \\
\text { maritime college } \\
\text { lecturers in DKI Jakarta. }\end{array}$ & 0,53 & 7,64 & 1.960 & $\begin{array}{l}\mathrm{H}_{0} \text { is rejected and } \mathrm{H}_{2} \text { is accepted. } \\
\text { The Work Environment has a } \\
\text { positive and significant effect on } \\
\text { job satisfaction of maritime } \\
\text { college lecturers in DKI Jakarta }\end{array}$ \\
\hline $\mathrm{H}$ & $\begin{array}{l}\text { There is an effect of } \\
\text { compensation on job } \\
\text { satisfaction of maritime } \\
\text { college lecturers in DKI } \\
\text { Jakarta. }\end{array}$ & 0,37 & 5,16 & 1.960 & $\begin{array}{l}\mathrm{H}_{0} \text { is rejected and } \mathrm{H}_{3} \text { is accepted. } \\
\text { Compensation has a positive and } \\
\text { significant effect on job } \\
\text { satisfaction of maritime college } \\
\text { lecturers in DKI Jakarta }\end{array}$ \\
\hline $\mathrm{H}$ & $\begin{array}{l}\text { There is an influence of } \\
\text { career development, } \\
\text { work environment and } \\
\text { compensation together } \\
\text { on job satisfaction of } \\
\text { maritime college } \\
\text { lecturers in DKI Jakarta. }\end{array}$ & 0,92 & 330,6 & 2,65 & $\begin{array}{l}\mathrm{H}_{0} \text { is rejected and } \mathrm{H}_{4} \text { is accepted. } \\
\text { Career Development, Work } \\
\text { Environment and Compensation } \\
\text { simultaneous to the job } \\
\text { satisfaction of maritime college } \\
\text { lecturers in DKI Jakarta }\end{array}$ \\
\hline
\end{tabular}

\section{Source: Appendix image Lisrel Output/SEM}

This research discusses the variables of Career Development, Work Environment, Compensation, Job Satisfaction and Permanent Lecturer. This research is in line with previous studies, including: (Elmi \& Ali, 2017), (Purba et al., 2017), (Riyanto et al., 2017), (Harini et al., 2020), Ali, H., \& Limakrisna, N. (2013). (Silitonga et al., 2017), (Limakrisna et al., 2016), (Agussalim et al., 2017)and (Masydzulhak et al., 2016).

\section{Conclusion}

1. Career development has been proven to have a positive and significant effect on job satisfaction of lecturers. The dominant dimension of career development is formed by the factor "ability in leadership" because it has a loading factor value of 0.89 higher than other dimensions and an indicator of "providing a different role to lecturers" with a loading factor value of 0.82 higher than other indicators.

2. The work environment is proven to have a positive and significant effect on job satisfaction of lecturers. The dominant dimension of the work environment is formed by the factor "physical environment" because it has a loading factor value of 0.89 
higher than other dimensions with an indicator of "temperature and air circulation" with a loading factor of 0.82 higher than other indicators.

3. Compensation is proven to have a positive and significant effect on job satisfaction of lecturers. The dominant dimension of compensation is formed by the "nonfinancial" factor because it has a loading factor value of 0.88 higher than other dimensions with a "good division of labor" indicator with a loading factor of 0.80 higher than other indicators.

4. Career development, work environment and compensation together have a positive and significant effect on job satisfaction of lecturers, with an $\mathrm{R}^{2}$ of 0.92 which provides information that as much as $92 \%$ of contributions made by career development, work environment and compensation together the same with job satisfaction of lecturers of maritime colleges in DKI Jakarta. The more dominant variable influencing lecturer job satisfaction is the work environment variable because it has a coefficient value in the structural equation of 0.53 higher than the value of other variables, and the calculated $F$ value (330.66) is higher than the $F$ table (2.65) . Other contributions to increasing job satisfaction of 0.08 or $8 \%$ have not been studied.

\section{Managerial Implications}

This research found that there is an influence of career development, work environment and compensation together on the job satisfaction of lecturers. Obtained $\mathrm{R}^{2}$ of 0.92 which provides information on the influence of $92 \%$. The work environment is the dominant factor influencing job satisfaction and its physical environment dimensions with a loading factor of 0.89 higher than other dimensions and an indicator of temperature and air circulation with a loading factor of 0.82 higher than other indicators. To increase lecturer job satisfaction, maritime colleges and related management need to improve the comfort of the lecturer work environment and together try to foster enthusiasm or rapid and appropriate career development to lecturers and apply and provide appropriate compensation in force in colleges in DKI Jakarta. Other factors that influence lecturer job satisfaction by 0.08 or by $8 \%$ may be influenced by other factors, including; leadership, organizational commitment and organizational culture that have not been studied by researchers.

\section{Suggestions}

The results of the model analysis and research hypothesis testing prove that there is a positive and significant influence between career development, work environment and compensation together on the job satisfaction of maritime college lecturers in DKI Jakarta, but what needs to be done is to maintain the lecturer work environment by emphasizing dimensions of the Physical Environment $\left(\mathbf{X}_{2.1}\right)$ with a loading factor of 0.89 because this dimension provides a reflection of the most dominant influence on job satisfaction variables and indicators of temperature and air circulation $\left(\mathrm{X}_{2 \_}\right)$with a loading factor of 0.82 and vice versa dimensions and indicators that need to be improved is the dimension of Achievement Opportunity $\left(\mathbf{X}_{1.1}\right)$ with a loading factor of 0.69 and an opportunity to develop achievement indicator $\left(\mathbf{X}_{\mathbf{1}} \mathbf{1}\right)$ because it provides the lowest reflection on job satisfaction of 0.72 . 


\section{Further Research Suggestions}

1. There are still many other factors that influence the job satisfaction of lecturers in the maritime colleges in DKI Jakarta such as leadership, organizational commitment, loyality, organizational culture, emotional ties, trust, convenience, experience with institutions and other factors for further investigation, because there may be factors Others have an influence on increasing lecturer job satisfaction.

2. This research was conducted at the maritime colleges in DKI Jakarta. It is hoped that further research can be carried out at maritime colleges other than in DKI Jakarta or with different objects that have the same characteristics as maritime colleges in DKI Jakarta, so that the benefits of the results of this study will be more extensive.

\section{REFERENCE}

Alex S Nitisemito, (2011), Manajemen Personalia (Manajemen Sumber. Daya Manusia, Edisi Kelima, Cetakan Keempat Belas, Jakarta, Ghalia Indonesia.

Ali, H., \& Limakrisna, N. (2013). Metodologi Penelitian (Petunjuk Praktis untuk Pemecahan Masalah Bisnis, Penyusunan Skripsi, Tesis, dan Disertasi). Deeppublish: Yogyakarta.

Andromike Maineldi dkk (2014), Pengaruh kompensasi dan lingkungan kerja terhadap loyalitas karyawan pada PT. Jatim Jaya Perkasa Kebun Banjar Balam Indragiri Hulu. JOM FEKON Vol. 1 No. 2

Agussalim, M., Limakrisna, N., \& Ali, H. (2017). Mutual Funds Performance: Conventional and Sharia Product. International Journal of Economics and Financial Issues.

Bernardin, Jhon H, and Joice E Russel, (2012), Humana Resources Management, Sixth Edition, New York, McGraw-Hill, Inc.

Byars, Lloyd L and Rue W, Leslie, (2011), Human Resource Management, Eighth Edition, Boston, McGraw-Hill.

Cascio F, Wayne, (2013), Managing Human Resources, London, McGraw-Hill.

Cherrington, David J, (2015), Organizational Behavior: The Management of Human Resource, Individual and Organizational Performance, Boston: Allyn and Bacon.

Elmi, F., \& Ali, H. (2017). The effect of incentive, training, and career development on productivity of PT. Pelita Cengkareng paper's workers. International Journal of Applied Business and Economic Research.

Griffin, Ricky W, Moorhead (2014), Organizational Behavior, Eleventh Edition, Boston, Houghton Miffilin Company.

Handoko, Triton PB, Hani, (2011), Manajemen Personalia dan Sumber Daya Manusia, Yogyakarta: Penerbit BPFE.

Hasibuan Malayu SP, (2013), Manajemen Sumber Daya Manusia, Edisi 2, Jakarta, Mas Agung.

Harini, S., Hamidah, Luddin, M. R., \& Ali, H. (2020). Analysis supply chain 
management factors of lecturer's turnover phenomenon. International Journal of Supply Chain Management.

Jordan E. Ayan (2012), Bengkel Kreativitas: 10 Cara Menemukan Ide-Ide Pamungkas melalui Pergaulan, Lingkungan, Perjalanan, Permainan, Bacaan, Seni, Teknologi, Berpikir, Alam Bawah Sadar, Jiwa Kreatif. Bandung: Kaifa.

Lawler and Ledford (2014), Human Resource Management, California, Handbooks of Organization.

Mangkunegara, (2012), Manajemen Sumber Daya Manusia Perusahaan, Cetakan ke 3, Bandung, PT. Remaja Rosda Karya.

Mathis, Robert L, and Jackson, Jhon H, (2011), Human Resource Management, Third Edition, Australia, South-Western.

Masydzulhak, P. D., Ali, P. D. H., \& Anggraeni, L. D. (2016). The Influence of work Motivationand Job Satisfaction on Employee Performance and Organizational Commitment Satisfaction as an Intervening Variable in PT. Asian Isuzu Casting Center. In Journal of Research in Business and Management.

Nawawi, Hadari, (2012), Manajemen Sumber Daya Manusia untuk Bisnis yang Kompetitif, Yogyakarta, Gadjah Mada University Press.

Limakrisna, N., Noor, Z. Z., \& Ali, H. (2016). Model of employee performance: The empirical study at civil servants in government of west java province. International Journal of Economic Research.

Purba, C. B., Arzio, \& Ali, H. (2017). The influence of compensation, working environment and organization culture on working productivity of BPJS (workers social security agency) employment staff in Rawamangun Branch. Man in India.

Rivai, Ella Djauhari, Sagala, (2013), Manajemen Sumber Daya Manusia untuk Perusahaan, Jakarta, Rajawali Pers.

Robbins, Stephen P, (2013), Organizational Behaviour, Nineth Edition, New Jersey, Prentice Hall.

Sedarmayanti, (2014), Manajemen Sumber Daya Manusia: Reformasi Birokrasi dan Manajemen Pegawai Negeri Sipil, Jakarta : PT Refika Aditama.

Simamora Henry, (2011), Manajemen Sumber Daya Manusia, Edisi Ketiga, cetakan kesatu, Yogyakarta, STIE YKPN.

Sinambela, L. Poltak. (2016), Manajemen Sumber Daya Manusia, Jakarta: PT Bumi Aksara.

Soelaiman, Sukmalana. (2010). Manajemen Kinerja : Langkah Efektif untuk Membangun, Mengendalikan dan Evaluasi Kerja. Jakarta : PT. Intermedia Personalia Utama.

Agussalim, M., Limakrisna, N., \& Ali, H. (2017). Mutual Funds Performance: Conventional and Sharia Product. International Journal of Economics and Financial Issues.

Elmi, F., \& Ali, H. (2017). The effect of incentive, training, and career development on productivity of PT. Pelita Cengkareng paper's workers. International Journal of Applied Business and Economic Research. 
Harini, S., Hamidah, Luddin, M. R., \& Ali, H. (2020). Analysis supply chain management factors of lecturer's turnover phenomenon. International Journal of Supply Chain Management.

Limakrisna, N., Noor, Z. Z., \& Ali, H. (2016). Model of employee performance: The empirical study at civil servants in government of west java province. International Journal of Economic Research.

Masydzulhak, P. D., Ali, P. D. H., \& Anggraeni, L. D. (2016). The Influence of work Motivationand Job Satisfaction on Employee Performance and Organizational Commitment Satisfaction as an Intervening Variable in PT. Asian Isuzu Casting Center. In Journal of Research in Business and Management.

Purba, C. B., Arzio, \& Ali, H. (2017). The influence of compensation, working environment and organization culture on working productivity of BPJS (workers social security agency) employment staff in Rawamangun Branch. Man in India.

Riyanto, S., Pratomo, A., \& Ali, H. (2017). EFFECT OF COMPENSATION AND JOB INSECURITY ON EMPLOYEE ENGAGEMENT (STUDY ON EMPLOYEE OF BUSINESS COMPETITION SUPERVISORY COMMISSION SECRETARIAT). International Journal of Advanced Research. https://doi.org/10.21474/ijar01/4139

Silitonga, P. E. S., Widodo, D. S., \& Ali, H. (2017). Analysis of the effect of organizational commitment on organizational performance in mediation of job satisfaction (Study on Bekasi City Government). International Journal of Economic Research.

Werther, William B, Jr, and Keith Davis, (2016), Human Resources and Personnel Management, Fifth Edition, Boston, USA, McGraw-Hill,.

Yuniarsih. (2013). Manajemen Sumber Daya Manusia, Bandung: Alfabeta. 